\title{
DOM/TALENTO E DOM/DÁDIVA: \\ duas modalidades de reciprocidade no mundo do futebol-espetáculo
}

por Marcus Vinícius Carvalho Garcia*

DAMO, Arlei Sander. Do dom à profissão: a formação de futebolistas no Brasil e na França. São Paulo: Aderaldo \& Rothschild: Ed. Anpocs, 2007. 359 p.

Do dom à profissão é baseado na tese de doutorado em antropologia social defendida por Arlei Sander Damo, em 2005, na Universidade Federal do Rio Grande do Sul. O estudo foi premiado em concurso de teses tanto pela Coordenação de Aperfeiçoamento de Pessoal de Nível Superior (Capes) quanto pela Associação Nacional de Pós-Graduação e Pesquisa em Ciências Sociais (Anpocs), que subsidiou a presente publicação. Abordando uma temática cada vez mais relevante nas ciências sociais, o autor investiga o mundo do futebol-espetáculo. Observa, analisa e traduz o fenômeno do futebol a partir de etnografia focada nos chamados centros de formação de atletas. Essas instituições, normalmente ligadas aos clubes profissionais, são responsáveis pela produção de jogadores para o mercado futebolista: o mercado de "pés-de-obra". Foi realizada pesquisa comparativa entre o centro de formação do Internacional, de Porto Alegre - RS, e o do Olympique, de Marselha, França. Também se realizaram observações em outras instituições, como o centro de formação do Athletic Bilbao (País Basco, Espanha), a empresa Talento S/A, localizada na Grande Porto Alegre - RS, e

\footnotetext{
* Doutorando em antropologia social pela Universidade de Brasília (UnB).
} 
várzeas e becos onde o futebol é praticado sem intuito profissional. Este estudo, porém, transcende a circunscrição do objeto central proposto, pois apresenta reflexão refinada sobre os bastidores do negócio do futebol e os contornos socioeconômicos e culturais desse esporte no contexto da globalização.

A formação em série dos atletas profissionais, operada por instituições especializadas nesse elo da cadeia produtiva do futebolespetáculo, é um fenômeno relativamente recente na história do esporte. É esse o eixo analítico do estudo e de onde partem as linhas que orientam o desvendamento de outras dimensões do mundo do futebol, como: a variedade de práticas futebolísticas; os meandros da "espetacularização"; a "mercadorização" de jogadores; as representações sobre o futebol entre jovens de classes sociais distintas; as relações de gênero e o estatuto da masculinidade. Esse rol de aspectos intrínsecos ao esporte gera o que o autor denominou "clubismo", que, para ele, configura uma espécie de totemismo moderno, já que este é a força motriz do futebol de espetáculo, dado que se trata de um fenômeno que conforma as comunidades de pertencimento e de afetividade às agremiações esportivas (p. 5051).

Arlei Damo "procura explicitar a trama simbólica que constitui o poder de sedução da profissão, bem como as redes de agenciamento que se beneficiam, dada a oferta abundante de dons/ talentos e praticamente nenhuma vigilância estatal da exploração desse mercado de trabalho e de pessoas" (p. 24). Considera-se, pois, que o processo de formação de futebolistas "é uma etapa que sucede a aquisição das técnicas elementares, não raro realizada à margem das instituições clubísticas, e antecede o exercício da profissão propriamente dita" (p. 22). Seria, então, essa fase na vida do aspirante a futebolista - se ensaiássemos uma metáfora inspirada no Processo Ritual de Victor Turner -- uma espécie de liminaridade, cujo sucesso ou fracasso depende de uma série de fatores, como adaptabilidade 
a situações de sobreesforço, cobrança/ausência familiar, solidão, abandono da escola, competição acirrada, invisibilidade, contusões e desencantos.

Esses fatores são todos tangenciados por questionamentos e juízos de valor acerca das aptidões técnicas, físicas e comportamentais suficientes para oreconhecimento profissionalde umjovem promissor, tanto para os garotos considerados talentos natos - dotados de dom, sugerindo-se uma capacidade diferenciada, que já vem pronta com eles, mas que precisa ser lapidada -, como para os que se dedicam a desenvolver, via esforço e abnegação, as competências necessárias para obter êxito. O autor é categórico em afirmar que, atualmente, não surgem jogadores profissionais fora dos centros de formação. É a passagem por essas instituições totais que insere os jovens atletas no mundo do futebol profissional. Nos centros, atua, silenciosamente, uma constelação de sujeitos - técnicos, olheiros, representantes de clubes, empresários e jornalistas - capazes de realizar a ponte entre os jovens futebolistas sonhadores e o mundo real da profissão.

Arlei Damo distingue três modelos - ou tipos ideais - de formação/produção de futebolistas: a produção endógena, a exógena e a híbrida. No modelo endógeno, o clube investe na formação de jogadores para suprir as próprias demandas por "pés-de-obra". É utilizado para baratear os custos de produção, bem como para atender às demandas de torcedores e associados desejosos de possuir atletas vinculados a uma instituição desde tenra idade. $\mathrm{O}$ exemplo do Athletic de Bilbao é o mais extremo, pois o clube é o representante da comunidade basca no certame nacional e, por isso, emprega somente atletas locais, como forma de demarcação de um orgulho étnico.

No modelo exógeno, a instituição é especializada na produção de atletas para o mercado clubístico. Exemplo desse modelo é a empresa Talento/SA. 
O modelo de produção híbrida é o praticado pela maioria dos principais clubes brasileiros - como o Internacional, já mencionado -, pois tanto formam a "prata-da-casa" quanto negociam atletas nos mercados nacionais e internacionais do futebol.

O nível de competitividade e de estresse exigido dos talentos precoces dentro dessas instituições, em relação às reduzidas possibilidades de ascensão, faz do futebol uma das profissões mais exigentes e excludentes - e talvez frustrantes - da sociedade brasileira. Isso contradiz, de certo modo, a crença do senso comum de que o país é um celeiro de craques. Se for, trata-se de um celeiro que não consegue absorver suficientemente a oferta de atletas, já que os postos de atuação se resumem a poucos clubes profissionais, sendo que a mínima parte destes oferece condições de suprir os desejos de glória e glamour evidenciados pelos meios de comunicação de massa, mesmo para o caso de atletas que vão atuar no exterior, onde o mercado é ainda mais acirrado, pois a minoria destes chega aos clubes de ponta. Não é somente a competência técnica dos jogadores brasileiros que os torna cobiçados nos mercados futebolísticos da Europa, da Ásia e, mais recentemente, do Oriente Médio - centros cada vez mais atentos à contratação de jovens atletas -, mas também a expressiva oferta de "pés-de-obra" associada ao baixo valor de seus contratos.

Acrescenta-se ainda o fato de que boa parte dos aspirantes a profissionais provém das camadas populares, em que o sonho de ascensão por meio do futebol ocupa seus anseios profissionais de modo a preterirem a educação formal e o desenvolvimento de outras aptidões. Isso passa a ser um problema social quando o atleta não consegue se profissionalizar, porque o período de formação do futebolista - entre os 10 e os 18 anos, aproximadamente - concorre com a fase fundamental para a formação escolar do cidadão. Nesse ponto - a chamada reconversão de atletas em cidadãos -, o autor enxerga diferenças radicais entre as formações "à brasileira" e "à 
francesa". Enquanto, no Brasil, o futebol é visto como uma das poucas alternativas de elevação social para os jovens pobres, na França, ele é apenas mais uma entre outras possibilidades. Ou seja, ser futebolista lá não exerce o mesmo fascínio que aqui.

Outra dimensão fundamental na diferença entre as duas tradições é que vigora, na França, legislação que obriga os clubes profissionais a oferecerem aos seus atletas aspirantes a possibilidade de freqüentarem a educação formal, paralelamente às atividades exclusivamente futebolísticas. Diferem também as tecnologias aplicadas, bem como as modalidades de contrato e ascensão na carreira, conforme os resultados alcançados, o mérito e as oscilações do mercado.

No escopo desse empreendimento intelectual notável considerando-se a qualidade da pesquisa etnográfica, sociológica e de arquivo, assim como a escrita exemplar -, o pesquisador oferece à literatura socioantropológica envolvente elaboração teórica em torno da clássica problemática da dádiva. Trata-se de perspicaz diálogo com esse paradigma muito em voga nas ciências sociais contemporâneas, especialmente, porque apresenta formulações sobre os sentidos atribuídos à noção de dom como sinônimo de talento e sobre seus paralelismos com o dom como sinônimo de dádiva. Busca verificar as nuanças dessa modalidade de distinção/ representação - o dom/talento - na formação de jovens atletas, bem como o dom/dádiva - a reciprocidade stricto sensu - como operador de relações e vínculos no mundo do futebol profissional.

Possuir ou não o "dom" é um tipo de assertiva que opera como estratégia de distinção e de status entre sujeitos não só no futebol, mas também em outros setores da vida social, como nas artes e na política. No caso dos jovens aspirantes a futebolistas, "o dom e as representações correlatas, que estão na origem de todos os investimentos conforme o ponto de vista nativo, matizam o processo 
de formação com um colorido social e cultural singularíssimo" (p. 24).

A estratégia escolhida para esmiuçar e decodificar esse colorido singular foi a exposição de narrativas etnográficas de alguns dramas sociais; por exemplo, o caso que envolve pai e filho brasileiros que chegam à França para fechar o contrato do garoto com um clube famoso e lá passam por dificuldades e desentendimentos diversos, processo este acompanhado de perto e participativamente pelo etnógrafo que, quando menos espera, se vê como intermediador da negociação (p. 215-221).

Esse e outros dramas vão se entrelaçando, no decorrer do texto, ao diálogo travado com a teoria antropológica, especialmente no capítulo 6, intitulado "O espectro do dom". O autor, entretanto, é cauteloso, pois considera prudente "evitar a todo o custo diluir os fatos empíricos em teorias preconcebidas" (p. 194), especialmente quando a problemática em tela - as teorias sobre a reciprocidade e a sua relação com os vínculos sociais - pode levar o pesquisador a subestimar uma teoria nativa, encobrindo-a com uma teoria geral, acadêmica e canônica. Ele afirma que "se acerca do dom se faz alguma modalidade de teoria, esta não é englobando e tampouco fundindo os horizontes, mas antes preservando as diferenças entre o ético e o êmico" (p. 195).

No modelo interpretativo apresentado, o dom/dádiva encontra-se tendente para o pólo ético. Ou seja, aplica-se a teoria geral na observação do fenômeno da reciprocidade no futebol e dali se desvendam meandros de seu funcionamento. Exemplifica-se isso com a narrativa sobre a carreira do jogador Iranildo, contida no documentário Futebol de João Moreira Salles. O filme documenta e o autor narra outra vez a trajetória do jogador e de sua família desde os tempos de dificuldades até quando ele começa a ter reconhecimento e, por isso, bons contratos e rendimentos repentinos. 
A família de Iranildo saiu do interior de Pernambuco impulsionada pela fé no talento do garoto. Em alguns poucos anos, após passar pelas categorias de base do Botafogo e por outros clubes do Rio, o jogador desponta no Flamengo e chega a ser convocado para a seleção brasileira. Aspecto interessante é a ingerência do pai sobre a carreira do atleta e a forma como, em torno deste, orbita uma série de atores com interesses distintos, mas que opera no registro da redistribuição segundo códigos muito particulares, obedecendo, contudo, a certa lei geral quanto à obrigatoriedade do circuito darreceber-retribuir, apesar da aparente forma conturbada como Iranildo e sua família - e boa parte dos boleiros - administram e retêm os ganhos do dom.

Arlei Damo chega a detectar, baseando-se no Ensaio sobre a dádiva, a idéia da circulação generalizada de coisas e homens, bem como os vínculos espirituais que isso engendra, a ponto de corroborar com Mauss, que salienta ser a força do dom que faz retornar a coisa ao seu lugar de origem. Isso é exemplificado no engajamento do pai de Iranildo em voltar para a pequena cidade de Igaraçu, pois, conforme explica, "aqui é muito importante pra gente... enquanto a maré estiver dando lá, a gente 'tá ganhando lá e vindo pra aqui... porque do lugar da gente não se pode fugir..." (p. 224). O autor conclui que,

[...] se o dom é uma predisposição, não é só futebolística. É preciso não se esquecer de Mauss para compreender os liames que o cercam, pois o que na origem era um atributo propriamente corporal converte-se em capital econômico, e ambos se tramam às representações produzidas dentro e fora do circuito futebolístico (p. 225).

Neste ponto do estudo, é desenvolvida relevante abordagem que interage com a fina flor do debate sobre a teoria da dádiva, desde a famosa interpretação do fenômeno por Claude Lévi-Strauss até as produções mais recentes - e contundentemente maussianas - de autores como Alain Caillé, Jacques Godbout e Camille Tarot. 
Do ponto de vista que tende ao pólo êmico da etnografia, ou seja, sensibilizando-se para o desvendamento da lógica e das categorias internas ao mundo do futebol, o autor busca revelar sutilezas da teoria nativa sobre o dom/talento. Parte do pressuposto de que o dom é um termo tão complexo e intangível como o amor, o ódio ou a saudade e que, só por isso, merece ser perscrutado em um exercício interpretativo. Defende que, apesar da possibilidade de sinonímica entre os termos "dom" e "talento" - ao ponto de eles poderem ser facilmente intercambiáveis -, há uma "dimensão residual e intangível das performances excepcionais que a palavra dom parece abarcar" (p. 191). Tal nuança simbólica é apresentada colocando-se em comparação as distintas percepções de dois profissionais especializados na descoberta e lapidação de atletas diferenciados, o que demonstra a polissemia do termo. Para um deles - o olheiro à moda antiga e de domínio prático -, prevalece a ambigüidade do discurso: o "jeito", o "algo mais", o "aquilo que você sabe que o sujeito tem, mas não sabe o que é", e, com isso, a percepção do dom como o que não é mensurado cognoscivelmente, mas existe, é representação, não substância. Para o outro - o profissional mais atento às tecnologias de produção, de domínio técnico-científico -, há uma articulação discursiva que não incorpora a noção de dom, porém acata a de talento. Para este último, o discurso segue nesta linha: "você consegue estabelecer no atleta uma relação entre capacidade intelectual global dos meninos e a capacidade para incorporar, aprender..." (p. 191).

Neste ponto da análise, pode-se considerar que é oferecida uma contribuição inspiradora, pois Arlei Damo defende que a noção de dom, conforme articulada no mundo do futebol, não comportaria a noção bourdieriana de habitus, uma tentação teórico-metodológica muito disseminada como estratégia de desnaturalização dos "mitos indígenas", conforme salienta. "Dom é fundamentalmente um termo 
que preenche um espaço que deveria ser ocupado por outro termo que não está disponível... um curinga, razão pela qual permanece oculto... um mistério.” (p. 199) E afirma: “O residual que a noção de dom protege, com mais vigor do que a noção de talento, e que a noção de habitus pretende liquidar, é essencial para meu argumento ser preservado" (p. 191-192).

Para ilustrar esse argumento, o autor ancora-se em depoimento de Ronaldinho Gaúcho, no qual a simples substituição do termo dom por talento não preservaria o sentido específico. Eis o depoimento: "Eu, eu tento me divertir, passar o tempo e fazer que as pessoas também se divirtam olhando meu jogo. Não há nada de mais, é do instinto, um dom que Deus me deu" (p. 192). O arremate do autor é à altura das boas jogadas de Ronaldinho:

O instinto ao qual Ronaldinho credita sua habilidade invulgar não é um mero dom/talento, e não se trata de vestir a carapuça de habitus, dizer que há nele uma natureza cultivada. Isto encobriria algo fundamental, que é a autopercepção do artista. Há algo que está nele, mas é algo mais, um dom que Deus lhe deu, uma dádiva, portanto. Ou seja, ele se percebe não apenas como portador, mas como receptor de um dom, uma espécie de predestinado ou vocacionado (p. 192).

Devido a esse aporte, o estudo de Arlei Damo é referência já quase obrigatória, não só para os especialistas em futebol, mas também para os pesquisadores interessados em desvendar especificidades sobre o dom como talento e como dádiva em outros contextos socioculturais, por exemplo, nas formas de transmissão e de aprendizagem da música e de outras artes. É referência, também, porque desenvolve um conjunto de novas noções - como "clubismo" e "capital futebolístico" -, assim como outras ferramentas analíticas para entender esse fenômeno de massa dos mais absorventes no século vinte. Por outro lado, do ponto de vista sociopolítico, Do 
dom à profissão: a formação de futebolistas no Brasil e na França traz provocações para o próprio campo futebolístico, pois descortina ilusões, disseca mitos surreais e mostra uma faceta obscura do esporte-espetáculo mais apreciado pelos brasileiros e por boa parte do restante do globo terrestre. 